\title{
Effect of soil type on wood chemical constituents and calorific values of 33-year-old Corymbia citriodora
}

\section{Efeito do tipo de solo sobre os constituintes químicos da madeira e o poder calorífico de Corymbia citriodora aos 33 anos}

\author{
Willyam de Lima Vieira ${ }^{1}$ (D), Erick Phelipe Amorim² (1), Miguel Luiz Menezes Freitas ${ }^{3}$ (D), \\ 'Universidade Estadual Paulista "Júlio de Mesquita Filho" - UNESP, Botucatu, SP, Brasil \\ ${ }^{2}$ Universidade Federal de São Carlos - UFSCar, Sorocaba, SP, Brasil \\ ${ }^{3}$ Instituto Florestal - IF, São Paulo, SP, Brasil \\ ${ }^{4}$ Universidade de São Paulo - USP, Piracicaba, SP, Brasil
}

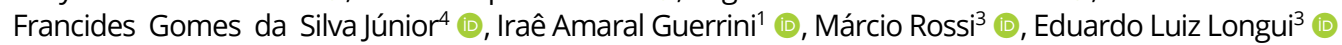

How to cite: Vieira, W. L., Amorim, E. P., Freitas, M. L. M., Silva Júnior, F. G., Guerrini, I. A., Rossi, M., \& Longui, E. L. (2021). Effect of soil type on wood chemical constituents and calorific values of 33-year-old Corymbia citriodora. Scientia Forestalis, 49(132), e3681. https://doi.org/10.18671/scifor.v49n132.06

\begin{abstract}
Red Latosol (LV), Red Nitosol (NV) and Quartzarenic Neosol (RQ) have different physical and chemical characteristics, as well as water holding capacity. This study aimed to determine how such differences cause changes in wood density, extractives, lignin and holocellulose contents, as well as higher heating value (HHV), lower heating value (LHV) and useful heating value (UHV), in C. citriodora wood. Wood density was lower in NV. We observed differences in chemical constituents of $C$. citriodora wood in all three soil types. Trees in RQ and LV soils have higher HHV, LHV and UHV values than trees in NV soil. We concluded that wood produced from all three soils is suitable for use in the Brazilian bioenergy market based on HHV values between 16500 and $18000 \mathrm{~kJ}^{\mathrm{kg}}$. Studies in the literature describe extractives and lignin as positively related, while holocellulose is negatively related to calorific value. In our study, wood density seems to have had a greater influence on calorific results than chemical constituents. It is possible that better water and nutrient availability from NV soil compared to RQ and LV soils may have led to higher tree growth, resulting in lower density and, hence, lower calorific values.
\end{abstract}

Keywords: Extractives; Holocellulose; Higher heating value; Lignin; Lower heating value; Wood density.

\section{Resumo}

O Latossolo Vermelho (LV), o Nitossolo Vermelho (NV) e o Neossolo Quartzarênico (RQ) apresentam características físicas e químicas distintas, além da capacidade de retenção de água. Este estudo teve como objetivo determinar como tais diferenças causam alterações na densidade da madeira, extrativos, teores de lignina e holocelulose, bem como o poder calorífico superior (HHV), poder calorífico inferior (LHV) e poder calorífico útil (UHV), em madeira de $C$. citriodora. A densidade da madeira foi menor em NV. Observamos diferenças nos constituintes químicos da madeira de $C$. citriodora nos três tipos de solo. Árvores em solos RQ e LV têm valores maiores de HHV, LHV e UHV do que árvores em solo NV. Concluímos que a madeira produzida nos três solos é adequada para uso no mercado brasileiro de bioenergia com base em valores de HHV entre 16500 e 18000 kJ.kg-1. Estudos na literatura descrevem extrativos e lignina como positivamente relacionados, enquanto a holocelulose está negativamente relacionada ao poder calorífico. Em nosso estudo, a densidade da madeira parece ter tido maior influência nos resultados caloríficos do que os constituintes químicos. É possível que uma melhor disponibilidade de água e nutrientes do solo NV em comparação com os solos RQ e LV possa ter levado a um maior crescimento da árvore, resultando em menor densidade e, portanto, menor poder calorífico.

Palavras-chave: Extrativos; Holocelulose; Poder calorífico superior; Lignina; Poder calorífico inferior; Densidade da madeira.

Financial support: Nothing to declare.

Conflict of interest: Nothing to declare.

Corresponding author: willyamvieira84@gmail.com

Received: 22 February 2021.

Accepted: 19 May 2021

Editor: Paulo Henrique Müller Silva.

(c) This is an Open Access article distributed under the terms of the Creative Commons Attribution License, which permits unrestricted use, distribution, and reproduction in any medium, provided the original work is properly cited. 


\section{INTRODUCTION}

Woody biomass represents a renewable resource with multiple industrial applications. It serves as a raw material for the pulp and paper industry, but it can also meet energy or biofuel needs (Hinchee et al., 2009).

The economic importance of $C$. citriodora in Brazil is more related to wood production for energy and lumber, as well as for the extraction of essential oils from leaves (Reis et al., 2013). The oils located in leaf glands are used to prepare medicines, industrial oils and perfumes (Vitti \& Brito, 2003). Recently, the use of $C$. citriodora has become more widespread, and its wood has come to be appreciated for applications in industry and furniture making owing to its qualities, but also due to the scarcity of certified wood (Vilas Bôas et al., 2009). C. citriodora wood is durable with little susceptibility to cracking (Cunha et al., 2019). However, the species is not yet favored by forestry companies in Brazil for cultivation (Vieira, 2004), leaving this chore to small and medium rural producers. Less use of the species $C$. citriodora results from the lack of extensive plantations and a short production cycle, even though C. citriodora is often compared to Eucalyptus species, which are generally grown in short cycles for cellulose, coal, or construction purposes (Cunha et al., 2019). In Australia, C. citriodora tolerates a variety of soils, but it is commonly found in poor, stony soils, podzols and residual podzols of lateritic origin, preferring well-drained, but somewhat stony soils (Nichols et al., 2010). In Brazil, it is used for reforestation in the central region of the country and the northeastern coast. The wide distribution of $C$. citriodora can be explained by its regional adaptability with different edaphic climatic conditions, good wood volumetric increment, and sprouting capacity after cutting (Reis et al., 2013). In São Paulo state, C. citriodora is susceptible to frost, but it is resistant to water deficit (Morais et al., 2011).

There is a wide range of uses of $C$. citriodora wood that can be widely used for buildings, structures, sleepers, and charcoal. It is also used for industrial production of chipboards (Iwakiri et al., 2000) and as coal demanded by the steel industry. Corymbia citriodora trees at 5 years of age could produce approximately 231.36 tons/ha of wood and this wood could attain 71.58 tons/ha of coal (Geromel et al., 2011).

In the present study, we investigated the wood of Corymbia citriodora (Hook.) K.D. Hill, \& L.A.S. Johnson (formerly Eucalyptus citriodora Hook.) in three soil types: Quartzarenic Neosol, Red Latosol and Red Nitosol. We aimed to clarify how physical, chemical and water holding capacity differences among these three types of soils can cause changes in wood density, extractives, lignin and holocellulose contents, as well as higher heating value, lower heating value and useful heating value in C. citriodora wood.

\section{MATERIAL AND METHODS}

\section{Provenances of the seeds, planting area and sampling}

In 1982, Corymbia citriodora seeds of open-pollinated plants were collected in commercial plantations in the Pederneiras State Forest, located in Pederneiras City, São Paulo State, Brazil $\left(22^{\circ} 27^{\prime} \mathrm{S}, 48^{\circ} 44^{\prime} \mathrm{W}\right.$, elevation $500 \mathrm{~m}$ ) where the climate is CWa. In 1983 , a progeny test was established with 56 progenies at the Luiz Antonio Experimental Station (LAES), Luiz Antônio

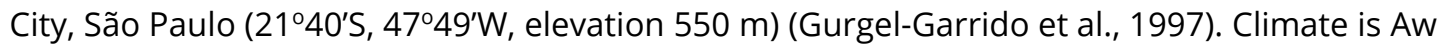
according to the Köppen-Geiger classification (Centro de Pesquisas Meteorológicas e Climáticas Aplicadas à Agricultura, 2019). The average annual rainfall is $1,365 \mathrm{~mm}$, and average annual temperature is $21.7^{\circ} \mathrm{C}$, with the warmest months occurring in January, February and March and the coldest months in May, June and July.

The planting was established at a spacing of $3 \mathrm{~m} \times 2 \mathrm{~m}$, with one external border row of the same species without fertilization. The planting was installed with the same design in three different soil types according to the Brazilian system of soil classification - SiBCS (Santos et al., 2018) and soil maps of Estação Experimental de Luiz Antônio (Santos et al., 2016). Site 1 has soil classified as Quartzarenic Neosol (symbol is RQ), site 2 as Red Latosol (LV), and site 3 as Red Nitosol (NV). The correspondences between classes of SiBCS compared with WRB/FAO, Soil Taxonomy/USDA are RQ 
(arenosols / quartzipsamments), LV (ferralsols / oxisols) and NV (nitisols / Oxisols - Kandic) by Santos et al. (2018).

In 2008, the LAES team determined height, DBH (diameter at breast height $-1.30 \mathrm{~m}$ from the ground) and stem shape, using a grading system, with values ranging from one (worst grade, crooked trunks) to five (best grade, straight trunks) and survival. In 2015, the LAES team conducted new growth, shape and survival analyses, but the competition among the trees was added. The 2008 and 2015 information served as basis for our selection of 18 trees (one of each progeny), the tallest and largest in diameter, for each type of soil, totaling 54 trees.

In 2016, we felled the selected trees, and from each tree, a log, 1 meter in length, was cut at the region immediately below breast height. From logs, a central plank $(5 \mathrm{~cm}$ thick) was cut, and from these planks, we cut three specimens in three radial positions: the nearest part of trunk center, designated as pith, a middle position, and a position close to the bark, designated as bark.

\section{Soil sampling and analysis}

We performed physical and soil water retention analysis according to Embrapa (Teixeira et al., 2017) in non-deformed samples. We collected samples at depths between $0-20 \mathrm{~cm}$, three points within plantation, and then we mixed samples to prepare a composite sample. We repeated the same procedure for each soil type. For texture analysis, we determined the percentages of sand, clay and silt. We also determined soil water retention content and soil bulk density with a volumetric cylinder for three samples of each soil type.

Air-dried soil samples were analyzed for phosphorus (P); aluminum (Al); $\mathrm{H}+\mathrm{Al}$; aluminum saturation (m\%); basic cations, including potassium (K), calcium (Ca), and magnesium (Mg); sum of the bases $\mathrm{Ca}$, $\mathrm{Mg}$ and $\mathrm{K}(\mathrm{SB})$; $\mathrm{pH}$; base saturation (V\%); micronutrients boron (B), copper $(\mathrm{Cu})$, iron (Fe), manganese (Mn) and zinc ( $\mathrm{Zn})$; cation exchange capacity (CEC) and total organic carbon (O.M.). Soil analysis was carried out according to the procedures described by Agronomic Institute of Campinas (van Raij et al., 1996).

\section{Density (p12)}

Wood density at $12 \%$ moisture content was determined according Glass \& Zelinka (2010). The mass and volume at $12 \%$ moisture content (MC) were evaluated. Specimens $2 \mathrm{~cm} \times 2 \mathrm{~cm} \times 3 \mathrm{~cm}$ in size were conditioned at constant temperature $\left(21^{\circ} \mathrm{C}\right)$ and $65 \% \mathrm{MC}$, respectively, and in these conditions, the mass was determined by the use of an analytical balance, and the volume was estimated by means of measurements of the diameters with an external digital micrometer.

\section{Chemical assays}

To determine extractives (EX) and lignin (LI) contents, TAPPI standards T204 (TAPPI, 1999a) and T222 (TAPPI, 1999b) were used, respectively. The samples were fragmented into smaller pieces with a hammer and chisel and milled in a micro mill. The resulting powder was sieved through 40 and 60 mesh screens, and the material retained on the last sieve was used for analysis. The analyses sequence was such that the extractives were first removed and then lignin by acid treatment, and holocellulose content was calculated. For extractive contents, solutions of toluene: alcohol (2:1 v:v) were employed, and alcohol extractions were performed at times exceeding $12 \mathrm{~h}$ in a Soxhlet extractor. For lignin, extractive-free powder was prepared in several stages with $72 \%$ sulfuric acid to obtain insoluble and soluble lignin (Cary 100 UV-visible spectrophotometer). Finally, the two values of lignin were added. Insoluble lignin (IL) content was determined as IL $=[(D W l i g) /(D W)]^{* 100}$, where DWlig = Dry weight of insoluble lignin and DW = Dry sawdust weight. For soluble lignin (SL), we analyzed filtrates, and the blanks were read at two wavelengths $(215 \mathrm{~nm}$ and $280 \mathrm{~nm}$ ) using quartz 
cuvettes. Soluble lignin content was determined as SL $=[4.53 *($ L.215 - blank $)-($ L.280 blank $\left.) /(300 * D W)^{*} 100\right]$, where DW $=$ Dry sawdust weight. Ex and Li were expressed as a percentage (\%) of oven-dry weight of unextracted wood. Then, the holocellulose (HO) content was determined as $\mathrm{Ho} \%=[100-\mathrm{Li}]$.

\section{Bioenergy values}

In this step, samples from pith to the bark (wood near the bark) were mixed. The moisture content was determined based on the methodology described by NBR 14929 (Associação Brasileira de Normas Técnicas, 2003) (Wood - Determination of the moisture content of chips - Method for oven drying). Wood chips were placed in a forced ventilation oven at $103{ }^{\circ} \mathrm{C} \pm 2{ }^{\circ} \mathrm{C}$ until constant mass was obtained. Mass is considered constant when no change in reading $( \pm 0.5 \mathrm{~g})$ occurs within a time interval of one hour after successive weighing was done. Moisture content was determined as MC = (WM - DM/DM) * $100(\%)$, where MC = moisture content (\%), WM = Sample wet mass (g) and DM = Sample dry mass (g).

We determined the Higher Heating Value (HHV) using an adiabatic calorimeter pump, according to NBR 8633 (Associação Brasileira de Normas Técnicas, 1984) (Charcoal Determination of calorific value - test). The samples were fragmented into smaller pieces with a hammer and chisel and milled in a micro mill. The resulting powder was sieved through 40 and 60 mesh screens, and the material retained on the last sieve was used for analysis. A $1 \mathrm{~g}$ sample was taken from each sample, homogenized and again separated into three fractions.

We determined Lower Heating Value (LHV) as LHV $=\mathrm{HHV}-[600 * 9 * \mathrm{H}) / 100]$, where $\mathrm{LHV}=$ Lower Heating Value $\left(\mathrm{kJ} \cdot \mathrm{kg}^{-1}\right), \mathrm{HHV}=$ Higher Heating Value $\left(\mathrm{kJ} \cdot \mathrm{kg}^{-1}\right)$, and $\mathrm{H}=$ Hydrogen (\%).

For calculation of Useful Heating Value (UHV), we used a moisture content of $20 \%$ on a dry basis (average value in which wood for burning firewood in poultry is used), which represents $16.67 \%$ moisture on a wet basis, which is the value used in the following equation: $\mathrm{UHV}=\mathrm{LHV}^{*}((100-\mathrm{U}) / 100)-6 * \mathrm{U}\left(\mathrm{kJ} \cdot \mathrm{kg}^{-1}\right)$, where UHV $=$ Useful Heating Value $\left(\mathrm{kJ} \cdot \mathrm{kg}^{-1}\right)$, $\mathrm{LHV}=$ Lower Heating Value $\left(\mathrm{kJ} \cdot \mathrm{kg}^{-1}\right)$, and $\mathrm{U}=$ Wet basis moisture content $(\%)$.

\section{Data Analyses}

To determine variations among wood density, chemical contents, and bioenergy values in three soil types, we initially undertook descriptive a statistical analysis and used the Box Plot graphics to detect outliers. Thus, values 1.5 times higher than the 3 rd quartile and values 1.5 times lower than the 1 st quartile were excluded from the analysis. Normality tests were performed to check the distribution of data, and when a normal distribution was not observed, data were square root-transformed. Then, a parametric analysis of variance (oneway analysis of variance (ANOVA)) was performed. When a significant difference was observed, Tukey's test was used to identify pairs of significantly different means. We also utilized a multivariate analysis via principal components analysis to verify the grouping of the different observed responses to different soil classes, taking into account the entire set of physical, chemical and heating value features. Because the measurement units differed between features, the data were log-transformed to reduce the effect of the numeric scale (McGarigal et al., 2000).

\section{RESULTS AND DISCUSSION}

\section{Soils}

According to granule size analyses, differences in texture were found in the three soil types. RQ is classified as sandy texture and has $52 \%$ coarse sand, $41 \%$ fine sand, $4 \%$ clay and $3 \%$ silt. LV is classified as medium texture and has $40 \%$ coarse sand, $41 \%$ fine sand, $16 \%$ clay 
and $3 \%$ silt. NV is classified as clayey texture and presented the lowest amount of coarse sand (6\%), fine sand (13\%) and the largest amount of clay (52\%) and silt (29\%) (Table 1).

Table 1. Physical attributes of three soil types (0-20 cm layer) of 33-year-old Corymbia citriodora plantings.

\begin{tabular}{|c|c|c|c|c|c|c|}
\hline \multirow{3}{*}{ Soils } & \multicolumn{3}{|c|}{ Sand } & \multirow{2}{*}{ Clay } & \multirow{2}{*}{ Silt } & \multirow{3}{*}{ Soil texture } \\
\hline & Coarse & Fine & Total & & & \\
\hline & \multicolumn{5}{|c|}{$\left(\right.$ g.kg $\left.^{-1}\right)$} & \\
\hline $\mathrm{RQ}$ & 516 & 415 & 930 & 43 & 27 & Sandy \\
\hline LV & 399 & 413 & 812 & 158 & 30 & Medium \\
\hline NV & 65 & 130 & 195 & 519 & 286 & Clayey \\
\hline
\end{tabular}

Quartzarenic Neosol (RQ); Red Latosol (LV); Red Nitosol (NV).

For chemical attributes, we observed differences in $\mathrm{pH}$, organic matter, macronutrients and micronutrients, and base saturation. We noticed the most acidic $\mathrm{pH}$ in LV, and organic matter is higher in NV. LV and RQ soils have high $\mathrm{Al}^{3+}$, but phosphorus, potassium, calcium and magnesium had low values. Sulfur has average reference values for the three soil types. On the other hand, significant differences were observed for micronutrients between $L V$ and $R Q$, with lower values, and $\mathrm{NV}$, with higher values. In all soils, high levels of iron, manganese and zinc were found with low values for LV and RQ. NV had high values for all macronutrients and micronutrients. According to the reference values, the base saturation (V\%) was very low for $\mathrm{LV}$ and $\mathrm{RQ}$ and intermediate for NV soils (Table 2). RQ had higher soil density, while NV had lower density and higher retained water (Table 3).

Table 2. Soil pH, organic matter and mineral nutrients in three soil types (0-20 cm layer) of 33-year-old Corymbia citriodora plantings.

\begin{tabular}{|c|c|c|c|c|c|c|c|c|c|c|c|c|c|c|c|c|c|c|}
\hline & pH & O.M & $\mathbf{P}$ & & & $\mathbf{K}$ & $\mathrm{Ca}$ & ivig & 3 & SB & CTC & \multirow{2}{*}{\multicolumn{2}{|c|}{$\mathbf{m} \% \mathrm{~V} \%$}} & B & $\mathrm{Cu}$ & $\mathbf{F e}$ & Mn & $\mathrm{Zn}$ \\
\hline & \multicolumn{4}{|c|}{$\mathrm{CaCl}_{2}{\mathrm{~g} \cdot \mathrm{dm}^{-3} \mathrm{mg} \cdot \mathrm{dm}^{-3}}^{-3}$} & \multicolumn{7}{|c|}{ - } & & & \multicolumn{5}{|c|}{ 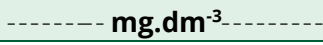 } \\
\hline $\mathrm{RQ}$ & 4.1 & 7 & 3 & 6 & 29 & 0.4 & 2 & & 7 & 3 & 32 & & $y$ & 0.15 & & & & 0,1 \\
\hline LI & 3. & & 4 & 10 & & 0. & 2 & & & & & & 5 & 0.20 & 4 & 8 & .9 & 0,1 \\
\hline NV & 4.6 & 24 & 96 & 1 & 92 & 6.1 & 62 & 13 & & 81 & 173 & 1 & 47 & 0.26 & 14.6 & 49 & 94.8 & 4,4 \\
\hline
\end{tabular}

Quartzarenic Neosol (RQ); Red Latosol (LV); Red Nitosol (NV); total organic carbon (O.M.); phosphorus (P); aluminum (Al); $\mathrm{H}+\mathrm{Al}$; potassium (K), calcium (Ca), magnesium (Mg); sulfur (S); sum of the bases $\mathrm{Ca}, \mathrm{Mg}$ and $\mathrm{K}(\mathrm{SB})$; cation exchange capacity (CEC); aluminium saturation (m\%); base saturation (V\%); boron (B), copper (Cu), iron (Fe), manganese (Mn) and zinc ( $\mathrm{Zn})$.

Table 3. Average retained water and soil density in three soil types $(0-20 \mathrm{~cm}$ layer $)$ of 33-year-old Corymbia citriodora plantings.

\begin{tabular}{|c|c|c|c|c|c|c|c|c|c|}
\hline \multirow{3}{*}{ Soils } & \multicolumn{8}{|c|}{ Retained water $\left(\mathrm{dm}^{3} \cdot \mathrm{dm}^{-3}\right)$} & \multirow{3}{*}{$\begin{array}{c}\text { Soil density } \\
\left(\mathrm{kg}^{\mathrm{dm}} \mathbf{3}^{-3}\right)\end{array}$} \\
\hline & \multicolumn{8}{|c|}{ Tension (MPa) } & \\
\hline & Saturated & 0.003 & 0.006 & 0.01 & $0.03^{\mathrm{FC}}$ & 0.1 & 0.5 & $1.5^{\mathrm{PWP}}$ & \\
\hline $\mathrm{RQ}$ & $0.43 c$ & $0.33 c$ & $0.22 c$ & $0.13 c$ & $0.09 c$ & $0.07 c$ & $0.06 c$ & $0.05 c$ & $1.85 a$ \\
\hline LV & $0.53 b$ & $0.39 b$ & $0.29 b$ & $0.19 b$ & $0.14 b$ & $0.12 b$ & $0.10 \mathrm{~b}$ & $0.10 \mathrm{~b}$ & $1.70 \mathrm{~b}$ \\
\hline NV & $0.63 a$ & $0.47 a$ & $0.44 a$ & $0.38 a$ & $0.33 a$ & $0.31 a$ & $0.29 a$ & $0.29 a$ & $1.51 \mathrm{c}$ \\
\hline
\end{tabular}

Quartzarenic Neosol (RQ); Red Latosol (LV); Red Nitosol (NV). FC = field capacity, PWP = permanent wilting point.

We observed differences in wood density and chemical constituents of $C$. citriodora wood in the three soil types. Wood density was lower in NV. We found differences in extractive contents, higher in NV and lower in RQ, and LV did not differ from NV and RQ. Lignin content was higher in LV, and holocellulose was higher in RQ (Table 4).

Table 4. Wood density ( $12 \%)$ and chemical constituents of 33-year-old Corymbia citriodora wood in three soil types.

\begin{tabular}{cccc}
\hline & Quartzarenic Neosol & Red Latosol & Red Nitosol \\
\hline$\rho 12 \%\left(\mathrm{~g} . \mathrm{cm}^{-3}\right)$ & $0.91 \mathrm{a}$ & $0.92 \mathrm{a}$ & $0.87 \mathrm{~b}$ \\
$\mathrm{EC}(\%)$ & $8.04 \mathrm{~b}$ & $8.97 \mathrm{ab}$ & $9.33 \mathrm{a}$ \\
\hline
\end{tabular}




\begin{tabular}{cccc}
\hline LC (\%) & $29.28 \mathrm{~b}$ & $30.14 \mathrm{a}$ & $29.85 \mathrm{~b}$ \\
$\mathrm{HC}(\%)$ & $62.66 \mathrm{a}$ & $60.88 \mathrm{~b}$ & $60.81 \mathrm{~b}$ \\
\hline
\end{tabular}

$\rho 12 \%$ = wood density; EC = extractive content; LC = lignin content; HC = holocellulose content. In the same row, distinct letters differ statistically $(P<0.05)$ by Tukey's test.

Regarding bio-energetic analysis, trees in RQ and LV soils had higher values of HHV, LHV and UHV compared to trees in NV soil (Table 5).

Table 5. Comparison among Higher Heating Value, Lower Heating Value and Useful Heating Value of 33year-old Corymbia citriodora in three soil types.

\begin{tabular}{cccc} 
& Quartzarenic Neosol & Red Latosol & Red Nitosol \\
\hline HHV $\left(\mathrm{kJ.kg}{ }^{-1}\right)$ & $20036 \mathrm{a}$ & $19949 \mathrm{a}$ & $19599 \mathrm{~b}$ \\
$\mathrm{LHV}\left(\mathrm{kJ} \cdot \mathrm{kg}^{-1}\right)$ & $18763 \mathrm{a}$ & $18676 \mathrm{a}$ & $18327 \mathrm{~b}$ \\
$\mathrm{UHV}\left(\mathrm{kJ} \cdot \mathrm{kg}^{-1}\right)$ & $16142 \mathrm{a}$ & $16218 \mathrm{a}$ & $15828 \mathrm{~b}$ \\
\hline
\end{tabular}

HHV = Higher Heating Value; $\mathrm{LHV}=$ Lower Heating Value; UHV = Useful Heating Value. In the same row, distinct letters differ statistically $(P<0.05)$ by Tukey's test.

Table 6 and Figure 1 show the correlations among the variables examined and the first and the second ordination axes responsible for $82.3 \%$ of the explanation of PCA. Axis 1 contributed $58 \%$ of the variability, and the variables which were most correlated with it were as follows: holocellulose content $(r=-0.979)$, lignin content $(r=0.917)$, and extractive content $(r=0.896)$. Axis 2 contributed $24.2 \%$ of the variability, and the variables with higher correlation coefficients were as follows: useful heating value $(r=0.887)$ and density $(r=0.576)$.

Table 6. Principal component analysis of physical and chemical properties and heating values of 33-yearold Corymbia citriodora in three soil types.

\begin{tabular}{ccc}
\hline & \multicolumn{2}{c}{ Principal Components } \\
\hline Variables & PC 1 & PC 2 \\
Density 12\% & 0.544 & 0.576 \\
Extractive content & 0.896 & -0.246 \\
Lignin content & 0.917 & 0.022 \\
Holocellulose content & -0.979 & 0.171 \\
Useful heating value & 0.060 & 0.887 \\
Percentage of explained variation & $58.09 \%$ & $24.22 \%$ \\
\hline
\end{tabular}

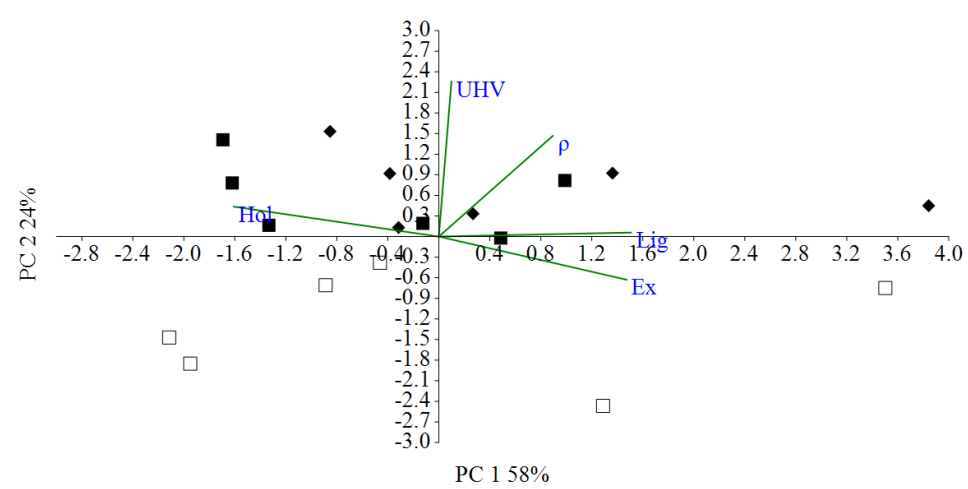

Figure 1. Ordination generated via principal components' analysis based on the entire dataset obtained from physical and chemical properties and heating values. Soil classes are represented by ( $\mathbf{\square})$

Quartzarenic Neosol, ( $\bullet$ ) Red Latosol and ( $\square$ ) Red Nitosol. Density 12\% ( $\rho)$, Contents of extractives (Ex), Contents of lignin (Lig), Contents of holocellulose (Hol) and Useful Heating Value (UHV). The percentage of variation explained by each principal component (PC1 and PC2) is shown. 
The three soil types significantly influenced wood density, chemical constituents and calorific value of C. citriodora wood. Calorific value is directly related to wood density (Dias \& Arroja, 2012). In a study of coal production from timber industry waste in northern Brazil, they reported that density is used as one of the parameters for selecting species with energy potential (Silva et al., 2007). Considering these statements, based on density, wood from RQ and LV trees presents higher potential for energy since the mean value (between radial positions) show a higher density when compared to wood from NV trees. Wood density results corroborate these statements since wood from NV trees presented the lowest values of HHV, LHV and UHV. It can be inferred that the more clayey and better structured soils have higher porosity ( $>$ micro porosity, > adsorption, > superficial tension and > capillarity), which implies greater retention and availability of moisture, providing less growth stress and, consequently, less wood density. However, in a study it was suggested that woods with lower densities and wood waste can be transformed into briquettes or pellets to increase calorific value (Quirino et al., 2005). The soil water retention occurs due to the structure in the low potential values, conditioned by the frequency of macro and micro-pores and by particle size and mineralogy in the high tensions. The texture determines the higher or lesser contact between soil particles and water, defining pore size. The structure defines particles' arrangement, determining pore distribution. Thus, clay soils have a great capacity to retain water due to its characteristics, such as a higher specific surface of particles, with consequent greater soil/water interaction, in addition to diversity of pores due to its structure. In sandy soil, infiltration is faster with less water retention due to the predominance of macro-pores, which allow more free drainage of water from the soil.

In one study it was observed that extractive contents in Eucalyptus grandis wood was not affected by soil attributes, while total lignin content decreased and holocellulose content increased when soil clay content increased (Gava \& Gonçalves, 2008). In the present study, we observed distinct results in C. citriodora in which extractive contents increased together with clay content in the soil, with lowest value in RQ and highest in NV. Whereas lignin content was higher in LV which has an intermediate clay content; holocellulose content was higher in RQ that has a lower clay content. We did not find studies in the literature to explain these results satisfactorily; Santana et al. (2012) reported that holocellulose and total lignin contents are hardly influenced by age, however in our study, sample collections were standardized in the trunk position, so we cannot suggest age as an indication of variation. In another study by our group (Vieira, 2019), we found that trees that grew in RQ soil had less volume compared to those in the other two soil types; perhaps this lower growth may have interfered with the higher holocellulose contents. Thus, results may vary, depending on the species, even though the soil type is the same, a phenomenon emphasized by Gava \& Gonçalves (2008) who also studied the chemical constituents of Eucalyptus grandis wood in Red Latosol, Yellow Red Latosol and Quartzarenic Neosol.

In addition to differences found in extractive contents among soil types for $C$. citriodora, age also plays a role. Our results on 33-year-old C. citriodora presented mean EC values from $8.04 \%$ to $9.33 \%$, similar to those found for older trees. Several studies with $C$. citriodora of different ages have found different values for extractive contents. The 32-year-old $C$. citriodora presented an average extractive content of $7.29 \%$ (Severo et al., 2006), while 10-year-old C. citriodora presented an average extractive content of 5.68\% (Costa et al., 2014), and 7-year-old C. citriodora presented an average extractive content of 6.25\% (Zanuncio et al., 2014).

Klumpers et al. (1993) studied the relationship between soil water amount and color heartwood in Quercus robur and Q. petraea. The authors found a positive relationship between soil water amount and heartwood color in $Q$. robur and that a more reddish heartwood was produced in trees where soil water was abundant in the spring. Based on the Klumpers finding, we were able to explain our results, since we observed a gradual increase in extractive content in relation to soil types, in which there is a lower extractive content in Quartzarenic Neosol, an intermediate extractive content in Red Latosol and a higher extractive content in Red Nitosol, considering the two extremes according to soil water retention potential (lower in RQ) and higher in (NV).

In a study which evaluated the effect of fertilization with $\mathrm{K}$ and $\mathrm{Na}$ on Eucalyptus grandis from 1 to 4 years under climatic conditions similar to those in the present study and dystrophic Red-Yellow Latosol soil with medium texture (200 g. kg-1 clay) the authors found no difference for extractive contents between fertilization and control treatments; however, differences did 
occur between different ages with $5.1 \%$ in the first year and $2.1 \%$ in the fourth year (Sette Junior et al., 2014).

Lignin contents from the three soil types did not present a similar response pattern to that found for the extractive contents. Between the soil classes NV and RQ no difference for lignin contents was observed, although both soils have distinct characteristics for physical, nutritional and water properties. LV resulted in a slight increase of lignin when compared to NV soil (0.97\%) and RQ soil (2.94\%). In 6-year-old Eucalyptus grandis x Eucalyptus urophylla clones Barbosa et al. (2019) found a positive correlation between lignin contents and rainfall and a negative correlation for water deficit in different localities under different climatic conditions.

For Eucalyptus grandis of an age of approximately 4 years old planted in three different fertile soils Sansígolo \& Ramos (2011) found that extractive contents showed no difference between the three soil types. Even when examining a trend from less fertile soil to more fertile soil, lignin content still showed no difference among soil types and did not respond in the same trend as soil fertility.

RQ soil resulted in the highest holocellulose content with a difference of $3 \%$ compared to other soils. We suggest that higher holocellulose content in our results is related to an increase in basic density. Similar results were found by (Melo et al., 2016) and (Arnaud et al., 2019) in the wood of Eucalyptus planted in low fertility and soils with water availability.

Extractives and lignin are positively related to calorific value (Telmo \& Lousada, 2011), and high lignin values are associated with higher charcoal gravimetric yield (Pereira et al., 2000). On the other hand, holocellulose is negatively related to calorific value; as the thermal degradation of holocellulose is faster than that of lignin (Costa et al., 2014). Therefore, wood with the highest potential for energy use would be that with higher extractive and lignin content, but with lower holocellulose content (Menucelli et al., 2019).

Based on this information, wood from LV trees with higher values of lignin and LV and NV wood based on higher extractive values would be most suitable for energy use. Wood from RQ presents the lowest potential for energy. However, when analyzing calorific results, we found that they did not follow the expected pattern for chemical constituents since wood from LV trees presented higher extractive contents, similar to LV wood, and lower lignin content, similar to RQ wood. Thus, it seems that density had a greater influence on calorific results than chemical constituents. From the principal components analysis, the separation of RQ and LV soils by chemical constituents (EC, LC and HC), when compared to NV, was clear. In Table 6, we identified that UHV showed lowest value in axis 1, but had highest participation in axis 2, contributing to the separation of samples from NV.

However, despite lower calorific values from NV, (Menucelli et al., 2019), studying the Brazilian market, reported that HHV values between 16500 and $18000 \mathrm{~kJ}^{. \mathrm{kg}^{-1}}$ are suitable values for use in bioenergy. Thus, although wood from all three soils in the present work is suitable for use in bioenergy, we suggest that Quartzarenic Neosol and Red Latosol are more suitable soils, since they resulted in higher energy values when compared to Red Nitosol values.

\section{CONCLUSION}

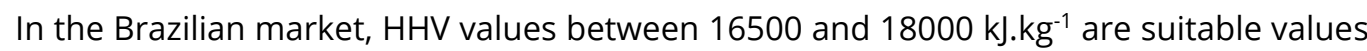
for use in bioenergy; therefore, wood from all three soils is suitable for bioenergy use. As reported in the literature, extractives and lignin are positively related, and holocellulose is negatively related to calorific value. In contrast, our study showed that wood density seemed to have a greater influence on calorific results than chemical constituents. It is possible that better water and nutrient availability from NV soil compared with RQ and LV may have led to higher tree growth, which resulted in lower density and, therefore, lower calorific values.

\section{ACKNOWLEDGEMENTS}

The authors thank Dirceu de Souza and Israel Luiz de Lima for fieldwork (Forestry Institute - IF), as well as the Laboratório de Química, Celulose e Energia, Escola Superior de Agricultura Luiz de Queiroz (ESALQ) and Universidade de São Paulo (USP), Piracicaba, Brasil. We 
also thank the Programa de Pós-Graduação em Planejamento e Uso de Recursos Renováveis UFSCAR/Sorocaba for support in developing this study. Erick Phelipe Amorim was supported by a Coordenação de Aperfeiçoamento de Pessoal de Nível Superior (Capes: Finance Code 001).

\section{REFERENCES}

Arnaud, C., Brancheriau, L., Sabatier, S., Heinz, C., Chaix, G., \& Tomazello-Filho, M. (2019). Interactions between the mechanical and hydraulic properties of eucalyptus trees under different environmental conditions of fertilization and water availability. BioResources, 14(3), 7157-7168.

Associação Brasileira de Normas Técnicas - ABNT. (1984). NBR 8633: carvão vegetal: determinação do poder calorífico. Rio de Janeiro: ABNT.

Associação Brasileira de Normas Técnicas - ABNT. (2003). NBR 14929: determinação do teor de umidade de cavacos: métodos por secagem em estufa. Rio de Janeiro: ABNT.

Barbosa, T. L., Oliveira, J. T. S., Rocha, S. M. G., Câmara, A. P., Vidaurre, G. B., Rosado, A. M., \& Leite, F. P. (2019). Influence of site in the wood quality of Eucalyptus in plantations in Brazil. Southern Forests, 81(3), 247-253. http://dx.doi.org/10.2989/20702620.2019.1570453.

Centro de Pesquisas Meteorológicas e Climáticas Aplicadas à Agricultura - CEPAGRI. (2019). Retrieved in 2019, May 20, from https://www.cpa.unicamp.br

Costa, T. G., Bianchi, M. L., Protásio, T. P., Trugilho, P. F., \& Pereira, A. J. (2014). Qualidade da madeira de cinco espécies de ocorrência no cerrado para produção de carvão vegetal. Cerne, 20(1), 37-45. http://dx.doi.org/10.1590/S0104-77602014000100005.

Cunha, G. M., Gama-Rodrigues, A. C., Gama-Rodrigues, E. F., \& Moreira, G. R. (2019). Nutrient cycling in Corymbia citriodora in the State of Rio de Janeiro, Brazil. Floresta e Ambiente, 26(2), 1-10. http://dx.doi.org/10.1590/2179-8087.020417.

Dias, A. C., \& Arroja, L. (2012). Environmental impacts of eucalypt and maritime pine wood production in Portugal. Journal of Cleaner Production, 37, 368-376. http://dx.doi.org/10.1016/j.jclepro.2012.07.056.

Gava, J. L., \& Gonçalves, J. L. M. (2008). Soil attributes and wood quality for pulp production in plantations of Eucalyptus grandis clone. Scientia Agrícola, 65(3), 306-313. http://dx.doi.org/10.1590/S0103-90162008000300011.

Geromel, G. K. S., Paula, N. F., \& Paula, R. C. (2011). Physicochemical characterization of wood and charcoal production of Corymbia citriodora. Ciência Tecnol Fatec-JB, 3, 1-4.

Glass, S. V., \& Zelinka, S. L. (2010). Physical properties and moisture relations of wood. In Forest Products Laboratory (Ed.), Wood handbook, wood as an engineering material (pp. 3.1-3.24). Madison: Forest Products Laboratory.

Gurgel-Garrido, L., Siqueira, A. C. M. F., Cruz, S. F., Romanelli, R. C., Ettori, L. C., Crestana, C. S. M., Silva, A. A., Morais, E., Scatena, A. C., \& Sato, A. S. (1997). Programa de melhoramento genético florestal do Instituto Florestal (IF Série Registros, No. 18, pp. 1-53). IPEF.

Hinchee, M., Rottmann, W., Mullinax, L., Zhang, C., Chang, S., Cunningham, M., Pearson, L., \& Nehra, N. (2009). Short-rotation woody crops for bioenergy and biofuels applications. In Vitro Cellular \& Developmental Biology. Plant, 45(6), 619-629. http://dx.doi.org/10.1007/s11627-009-9235-5.

Iwakiri, S., Cruz, C. R., Olandoski, D. P., \& Brand, M. A. (2000). Utilização de resíduos de serraria na produção de chapas de madeira aglomerada de Eucalyptus saligna, Eucalyptus citriadora e Eucalyptus pilularis. Floresta e Ambiente, 7, 251-256.

Klumpers, J., Janin, G., Becker, M., \& Lévy, G. (1993). The influences of age, extractive content and soil water on wood color in oak: the possible genetic determination of wood color. Annales des Sciences Forestieres, 50(Suppl.), 403-409. http://dx.doi.org/10.1051/forest:19930746.

McGarigal, K., Cushman, S., \& Stafford, S. (2000). Multivariate statistics for wildlife ecology research. New York: Springer. http://dx.doi.org/10.1007/978-1-4612-1288-1.

Melo, L. E. L., Silva, J. R. M., Napoli, A., Lima, J. T., Trugilho, P. F., \& Nascimento, D. F. R. (2016). Influence of genetic material and radial position on the anatomical structure and basic density of wood from Eucalyptus spp. and Corymbia citriodora. Scientia Forestalis, 44(111), 611-621. http://dx.doi.org/10.18671/scifor.v44n111.07.

Menucelli, J. R., Amorim, E. P., Freitas, M. L. M., Zanata, M., Cambuim, J., Moraes, M. L. T., Yamaji, F. M., Silva Júnior, F. G., \& Longui, E. L. (2019). Potential of Hevea brasiliensis clones, Eucalyptus pellita and Eucalyptus tereticornis wood as raw materials for bioenergy based on higher heating value. BioEnergy Research, 12(4), 992-999. http://dx.doi.org/10.1007/s12155-019-10041-6. 
Morais, E., Zanatto, A. C. S., Moraes, M. L. T., Freitas, M. L. M., \& Sebbenn, A. M. (2011). Comportamento e variação de procedências de Corymbia citriodora em diferentes tipos de solos. Floresta, 41(2), 277286. http://dx.doi.org/10.5380/rf.v41i2.21875.

Nichols, J. D., Smith, R. G. B., Grant, J., \& Glencross, K. (2010). Subtropical eucalypt plantations in eastern Australia. Australian Forestry, 73(1), 53-62. http://dx.doi.org/10.1080/00049158.2010.10676310.

Pereira, J. C. D., Sturion, J. A., Higa, A. R., Higa, R. C. V., \& Shimizu, J. Y. (2000). Características da madeira de algumas espécies de eucalipto plantadas no Brasil (113 p.). Colombo: Embrapa Florestas.

Quirino, W. F., Vale, A. T., Andrade, A. P. A., Abreu, V. L. S., \& Azevedo, A. C. S. (2005). Poder calorífico da madeira e de materiais ligno-celulósicos. Revista da Madeira, (89), 100-106.

van Raij, B., Cantarella, H., Quaggio, J. A., \& Furlani, A. M. C. (Eds.). (1996). Recomendações de adubação e calagem para o Estado de São Paulo (2. ed., 285 p.). Campinas: Instituto Agronômico.

Reis, C. A. F., Assis, T. F., Santos, A. M., \& Paludzyszyn Filho, E. (2013). Corymbia citriodora: estado da arte de pesquisas no Brasil. Colombo: Embrapa Florestas.

Sansígolo, C. A., \& Ramos, É. S. (2011). Quality wood pulp from a clone of Eucalyptus grandis planted at three locations. Cerne, 17(1), 47-60. http://dx.doi.org/10.1590/S0104-77602011000100006.

Santana, W. M. S., Calegario, N., Arantes, M. D. C., \& Trugilho, P. F. (2012). Effect of age and diameter class on the properties of wood from clonal Eucalyptus. Cerne, 18(1), 1-8. http://dx.doi.org/10.1590/S0104-77602012000100001.

Santos, A. A., Rossi, M., Kanashiro, M. M., \& Duarte, D. (2016). Caracterização do meio físico da estação experimental de Luiz Antônio: ênfase em solos. In Anais do $10^{\circ}$ Seminário de Iniciação Científica do Instituto Florestal (p. 43). São Paulo: Instituto Florestal.

Santos, H. G., Jacomine, P. K. T., Anjos, L. H. C., Oliveira, V. Á., Lumbreras, J. F., Coelho, M. R., Almeida, J. A., Araujo Filho, J. C., Oliveira, J. B., \& Cunha, T. J. F. (2018). Sistema brasileiro de classificação de solos (5. ed.). Brasília: Embrapa.

Sette Junior, C. R., Tomazello Filho, M., Silva Júnior, F. G., \& Laclau, J. P. (2014). Changes in chemical properties of wood with substitution of $\mathrm{K}$ by $\mathrm{Na}$ in Eucalyptus plantations. Revista Árvore, 38(3), 569578. http://dx.doi.org/10.1590/S0100-67622014000300020.

Severo, E. T. D., Calonego, F. W., \& Sansígolo, C. A. (2006). Composição química da madeira de Eucalyptus citriodora em função das direcções estruturais. Silva Lusitana, 14(1), 113-126.

Silva, M. G., Numazawa, S., Araujo, M. M., Nagaishi, T. Y. R., \& Galvão, G. R. (2007). Charcoal from timber industry residues of three tree species logged in the municipality of Paragominas, PA. Acta Amazonica, 37(1), 61-70. http://dx.doi.org/10.1590/S0044-59672007000100007.

Technical Association of Pulp and Paper Industry - TAPPI. (1999a). T204 cm-97: Technical association of pulp and paper industry: solvent extractives of wood and pulp. Atlanta: TAPPI.

Technical Association of Pulp and Paper Industry - TAPPI. (1999b). T222 om-98: acid: insoluble lignin in wood and pulp. Atlanta: TAPPI.

Teixeira, P. C., Donagemma, G. K., Fontana, A., \& Teixeira, W. G. (2017). Manual de métodos de análise de solo (3. ed. rev., 574 p.). Brasília: Embrapa.

Telmo, C., \& Lousada, J. (2011). Heating values of wood pellets from different species. Biomass and Bioenergy, 35(7), 2634-2639. http://dx.doi.org/10.1016/j.biombioe.2011.02.043.

Vieira, I. G. (2004). Estudo de caracteres silviculturais e de produção de óleo essencial de progênies de Corymbia citriodora (Hook) K.D.Hill \& L.A.S. Johnson procedente de Anhembi SP - Brasil, Ex. Atherton QLD - Austrália (Dissertação de mestrado). Piracicaba: Escola Superior de Agricultura "Luiz de Queiroz", Universidade de São Paulo.

Vieira, W. L. (2019). Propriedades físicas e mecânicas, características anatômicas e constituintes químicos da madeira de Corymbia citriodora (Hook.), K. D. Hill, \& L. A. S. Johson em três tipos de solo. Botucatu: Faculdade de Ciências Agronômicas, Univesridade Estadual Paulista.

Vilas Bôas, O., Max, J. C. M., \& Melo, A. C. G. (2009). Crescimento comparativo de espécies de Eucalyptus e Corymbia no município de Marília, SP. Revista do Instituto Florestal, 21(1), 63-72.

Vitti, A. M. S., \& Brito, J. O. (2003). Óleo essencial de Eucalipto (Documentos Florestais, No. 17, pp. 1-26). Piracicaba: Escola Superior de Agricultura "Luiz de Queiroz", Universidade de São Paulo.

Zanuncio, A. J. V., Carvalho, A. G., Trugilho, P. F., \& Monteiro, T. C. (2014). Extractives and energetic properties of wood and charcoal. Revista Árvore, 38(2), 369-374. http://dx.doi.org/10.1590/S010067622014000200018. 
Authors' contributions: WLV: conceptualization, data curation, formal analysis, investigation, Writing - original draft, Writing - review \& editing; EPA: investigation; MLMF: writing - review \& editing; FGSJ: writing - review \& editing, resources; IAG: writing - review \& editing, investigation; MR: writing - review \& editing, investigation. ELL: conceptualization, supervision, validation, writing - review \& editing. 